\title{
Aneka Olahan Sukun, Salak dan Daun Mangga Khas Kabupaten Bangkalan
}

\author{
Yudhi Rachman \\ Fakultas Ilmu Sosial dan Ilmu Budaya Universitas Trunojoyo Madura \\ E-mail : yudhi.rachman@trunojoyo.ac.id
}

DOI: https://doi.org/10.21107/pangabdhi.v6i1.7482

Naskah diterima 2 Februari 2020, Revisi 30 Maret 2020, Terbit 19 April 2020

\begin{abstract}
Abstrak
Tulisan ini mencoba menampilkan upaya pemberdayaan melalui kegiatan KKN Mahasiswa Tematik Mandiri Tahun 2018/2019 Universitas Trunojoyo Madura di 3 Desa Ujung Barat Kabupaten Bangkalan. Belajar dan berbagi dengan masyarakat desa yang sebagian besar adalah petani tadah hujan dengan memanfaatkan potensi sumber daya baik tanaman dan alam yang tersedia, berbagai kegiatan baik penyuluhan dengan berbagai tema dan pelatihan keterampilan pemasaran produk unggulan sukun di Desa Sembilangan, buah salak dan bambu di Desa Kramat serta pengenalan inovasi produk alternatif seperti teh dan sirup berbahan daun mangga yang berlimpah dan tidak termanfaatkan di Desa Ujung Piring. Kesemuanya itu diharapkan mampu meningkatkan akses, kekuatan dan kemampuan bagi masyarakat desa pengolah produk untuk menjadi Desa Sejahtera.
\end{abstract}

Kata kunci: komoditas unggulan, pemberdayaan masyarakat

\section{PENDAHULUAN}

Desa dalam pengertian UU Nomor 32 Tahun 2004 adalah kesatuan masyarakat hukum yang memiliki batas wilayah, yang berwenang untuk mengatur dan mengurus kepentingan masyarakat setempat, berdasarkan asal-usul dan adat istiadat setempat yang diakui dan dihormati dalam system pemerintahan Negara Kesatuan Republik Indonesia.

Berdasar pengertian tersebut, sebetulnya desa merupakan bagian penting bagi keberadaan bangsa Indonesia. Penting karena desa merupakan satuan terkecil dari bangsa ini yang menunjukkan keragaman Indonesia. Selama ini terbukti keragaman tersebut telah menjadi kekuatan penyokong bagi tegak dan eksisnya bangsa. Dengan demikian penguatan desa menjadi hal yang tak bisa ditawar dan tak bisa dipisahkan dari pembangunan bangsa ini secara menyeluruh.

Warga pedesaan, suatu masyarakat mempunyai hubungan yang erat dan lebih mendalam ketimbang hubungan dalam masyarakat kota. Sistem kehidupan sosial bersifat berkelompok kebanyakan atas dasar sistem kekeluargaan. Penduduk masyarakat pedesaan pada umumnya hidup dari pertanian. Walaupun terlihat adanya tukang kayu, tukang bangunan, tukang genteng dan bata bahkan tukang catut (sistem ijon), inti pekerjaan penduduk adalah pertanian. Pekerjaan pekerjaan disamping pertanian hanya pekerjaan sambilan (Soekanto, 2012)

Universitas Trunojoyo Madura berkomitmen melakukan pemberdayaan desa salah satunya dengan kegiatan KKN Tematik Mandiri 2018/2019. Penulis berkesempatan menjadi DPL (Dosen Pembimbing Lapangan) 3 Kelompok yang masing-masing beranggotakan 15 Mahasiswa/i yang ditempatkan di 3 Lokasi Desa yang berada di Kecamatan Bangkalan yaitu :

(1) Kelompok 9 di Desa Sembilangan;

(2) Kelompok 16 di Desa Ujung Piring

(3) Kelompok 36 di Desa Kramat

Dari realitas sosial yang dikemukakan dalam latar belakang diatas, maka kegiatan KKN Tematik Mandiri ini berkomitmen untuk melakukan upaya pemberdayan desa dengan berbagai kegiatan dan program yang telah diagendakan. Persoalan mendasar dari kegiatan KKN yang relatif singkat tersebut adalah strategi dan bentuk kegiatan apa yang bisa meningkatkan pengetahuan dan keterampilan warga sehingga mampu meningkatkan daya saing produk unggulan

\section{METODE}

Lokasi kegiatan pengabdian masyarakat adalah 3 Desa yaitu Desa Ujung Piring, Desa Sembilangan dan Desa Kramat yang terletak di kecamatan Bangkalan. Melalui kegiatan KKN Mahasiswa Tematik Mandiri Tahun 2018/2019 
Universitas Trunojoyo Madura sebagai upaya pemberdayaan usaha - usaha unggulan yang dimiliki masyarakat setempat. Melalui serangkaian kegiatan pelatihan baik skill dan produk yang dihasilkan selama masa pelaksanaan kegiatan KKN mulai Tanggal 26 Desember 2018 sampai dengan 21 Januari 2019 melalui program kerja dan rencana kegiatan yang telah dibuat masing - masing kelompok KKN Mandiri ini.

\section{HASIL DAN PEMBAHASAN}

Bangkalan merupakan salah satu kabupaten yang terletak paling barat di kepulauan Madura. Pulau Madura merupakan bagian dari Propinsi Jawa Timur yang terpisah dari kabupatenkabupaten lain yang masuk dalam Propinsi Jawa Timur. Lokasi 3 Desa KKN Tematik Mandiri yang dibahas dalam tulisan ini berada di wilayah Pusat Pemerintahan yaitu di sebelaah selatan pusat Kecamatan Bangkalan yang berbatasan dengan selat madura dan kecamatan Socah.

Sumber daya lahan di 3 Desa Lokasi KKN Tematik kebanyakan bersifat sawah tadah hujan dibandingkan sawah irigasi yang lebih produktif masa tanamnya. Petani penanam padi tadah hujan selalu mendapati dirinya tergantung kepada kondisi alam yang sulit diprediksi. Dari sekian banyak teknik yang ada ia dapat memilih rutin yang meminimalkan kegagalan, akan tetapi karena mempunyai batas yang yang kecil, maka dengan teknik yang paling baik sekalipun tetap rentan.

Pelatihan Pengelolaan Keripik Sukun dan Pegagan di Desa Sembilangan

Sukun merupakan salah satu bahan makanan paling populer di Indonesia. Meskipun masih jarang yang menjadikan nya sebagai makanan pokok seperti nasi, namun banyak yang mengolah sukun menjadi makanan ringan. Keripik sukun ini hanya diolah dengan mudah yaitu sukun dibersihkan, dicuci, dan diberi bumbu sederhana yang kemudian digoreng. Keripik sukun ini memiliki empat rasa, seperti: original, rasa manis, rasa asin dan rasa balado. Dalam proses pengolahan sukun hal yang ditakutkan yaitu ketika terjadi perubahan musim yang membuat sukun tersebut sulit untuk ditemukan.

Salah satu komoditas hasil kebun yang ada di Desa Sembilangan adalah sukun dan pegagan. Tanaman sukun tumbuh berjejer di sepanjang samping jalan Desa Sembilangan sehingga keberadaannya melimpah. Sedangkan pegagan banyak ditemukan di sawah-sawah warga desa
Sembilangan. Akan tetapi selama ini, potensi tersebut tidak dimanfaatkan secara optimal mengenai metode pengolahan serta prospeknya ke depan sehingga sukun dan pegagan masih memiliki nilai jual yang rendah. Masyarakat Desa Sembilangan umumnya memasarkan sukun dalam keadaan mentah dan jalur distribusinya hanya di daerah setempat. Oleh karena itu, guna menambah pengetahuan warga dan peningkatan nilai ekonomis sukun serta sebagai pemenuhan kebutuhan masyarakat modern yang serba dinamis, KKN 09 mengadakan pelatihan pembuatan keripik dari sukun dan pegagan dengan berbagai macam aneka rasa.

Hasil pembuatan keripik pegagan tersebut akan diperjual belikan serta dipamerkan dalam pameran KKN. Masyarakat diberikan ilmu dalam proses pembuatan keripik pegagan dari awal hingga akhir. Hal-hal yang perlu diperhatikan dalam pembuatan keripik pegagan adalah kreatifitas, ketelatenan, kerapian, rasa dan hasil. Diharapkan program pelatihan pembuatan keripik pegagan ini dapat berjalan dengan baik dan berlanjut sebagai sarana menambah wawasan dan penghasilan tambahan masyarakat Desa Sembilangan.

\section{Teh dan Sirup Berbahan Daun Mangga Ala Desa Ujung Piring}

Produk unggulan ini dibuat dengan memanfaatkan potensi yang ada di Desa Ujung Piring. Salah satu potensi yang dapat dijadikan produk unggulan di Desa Ujung Piring yaitu buah mangga dan daun mangga. Setiap rumah warga di Desa Ujung piring memiliki tanaman mangga.

Berawal dari keadaan tersebut Kelompok KKN 16 ingin menciptakan produk unggulan yang bisa memanfaatkan potensi di Desa Ujung Piring yaitu buah dan daun mangga. Sehingga dapat membantu memecahkan masalah yang dihadapi warga desa Ujung Piring setiap musim mangga. Produk unggulan tersebut nantinya juga dapat di terapkan oleh masyarakat dan dapat menjadi makanan khas desa Ujung Piring. Hal tersebut juga akan menambah pendapatan desa jika masyarakat luas sudah mengenal potensi dari produk teh berbahan dau mangga tersebut, cara Pembuatannya cukup sederhana, yaitu cuci bersih daun manga. Jemur daun mangga dibawah sinar matahari hingga kering sampai bisa diremas seperti daun teh. Teknik pengeringan juga bisa menggunakan oven, kemudian yang ketiga. daun mangga yang sudah kering diremas-remas hingga seperti daun teh. Remasan daun mangga di rebus, 
hingga mendidih dan didinginkan. Saring rebusan daun mangga tambahkan gula dan kayu manis sesuai selera.

Strategi Pemasaran Dan Branding Aneka olahan Salak Dari Desa Kramat.

Strategi pemasaran dalam suatu usaha sangatlah penting. Pemilihan strategi pemasaran yang salah akan berakibat kurang laris-nya hasil jual produk. Selama ini Kelompok tani Ambudi Makmur 2 menjual hasil olahan salak mereka dengan cara menunggu konsumen yang datang ke rumah produksi untuk membeli produk yang dijual. Terkadang mereka juga melakukan strategi pemasaran dengan mengikuti pameranpameran UMKM yang diadakan di daerahdaerah. Dengan strategi pemasaran tersebut dirasa kurang cocok untuk memperkenalkan dan juga memaksimalkan produk yang dijual.

Kelompok KKN 36 dari Universitas Trunojoyo Madura berinisiatif untuk mencoba strategi pemasaran dengan menjemput konsumen atau pembeli. Menjemput konsumen ini dimaksudkan agar produk yang dijual tidak ada perantara lain antara penjual dan pembeli dan juga untuk memperkenalkan olahan salak yang khas dari Desa Kramat keluar desa, khususnya di Kabupaten Bangkalan.

Pemasaran produk olahan Ambudi Makmur 2 desa Kramat adalah program kerja yang disusun oleh mahasiswa KKN 36 dengan melihat masalah yang ada di strategi pemasaran kelompok tani tersebut. Solusi yang diberikan dengan menerapkan strategi pemasaran menjemput konsumen atau pembeli agar dapat memaksimalkan produk yang dijual. Selain itu, dengan cara ini pengenalan produk ke masyarakat luas juga dapat dilakukan.

\section{a. Pelatihan Digital Marketing}

Digital marketing adalah suatu usaha untuk melakukan pemasaran sebuah brand atau produk melalui dunia digital atau internet. Tujuannya ialah untuk menjangkau konsumen maupun calon konsumen secara lebih luas. Selama ini kelompok tani Ambudi Makmur 2 dan karang taruna desa hanya memahami cara menggunakan sosial media namun, tidak mengetahui cara memasarkan produk menggunakan sosial media. Digital marketing yang digunakan pada kegiatan di Desa Kramat ada 2, yaitu Instagram dan Facebook.

Setiap hari Kamis kelompok KKN 36 mela ksanakan kegiatan pelatihan digital marketing bertempat di balai Desa Kramat Bangkalan.
Antusias dan juga keinginan audien untuk mengikuti kegiatan ini menunjukkan adanya keinginan untuk melakukan perubahan mengikuti perkembangan trend penjualan melalui internet. Dukungan dan Kehadiran Kepala desa serta tokoh masyarakat juga sangat berpengaruh dalam kelancaran pelatihan digital marketing.

\section{b. Pelatihan Pembuatan Keranjang Salak dari} Bambu

Desa Kramat merupakan daerah sentra pengolahan salak. Buah salak di oleh menjadi beberapa olahan seperti: dodol salak, kurma salak, kripik salak, sirup salak, kismis salak, coklat salak, kopi biji salak, dan masih banyak yang lainnya. Usaha pengolahan salak ini bermula dari melimpahnya buah salak pada saat musim panen salak. Pada saat musim panen salak buak salah tidak dapat di terima pasar secara menyeluruh. Buah salak yang kurang baik akan terbuang secara cuma- cuma.

Tetapi kini buah salak kualitas kedua dapat di manfaatkan menjadi produk olahan yang di kelola oleh Kelompok Tani Ambudi Makmur 2. Dibalik itu semua masih terdapat kendala yang cukup kompleks yakni kemasan pemasaran buah salak segar. Guna memanfaatkan sumberdaya alam yang tersedia pada desa tersebut dengan menyulap bambu menjadi kerajinan keranjang yang berguna sebagai kemasan buah salak segar yang berkualitas baik.

\section{KESIMPULAN}

Rencana dan program kerja serta kegiatan yang dilaksanakan oleh Kelompok KKN 9 Sembilangan, Kelompok 16 Ujung Piring dan Kelompok 36 Kramat di rancang dengan tujuan utama melakukan pemberdayaan terhadap masyarakat desa yang sebagian besar adalah petani. Tentu saja waktu KKN yang relatif singkat belum dapat menunjukkan hasil yang signifikan baik dari sisi peningkatan kualitas SDM maupun keuntungan besar secara ekonomis. Tetapi memberikan modal dasar yang cukup untuk melangkah maju kedepan.

\section{DAFTAR PUSTAKA}

Septiawan, S. 2007. Menulis Ilmiah: Metode Penelitian Kualitatif. Jakarta: Yayasan Obor Indonesia

Moleong, L. J. 2004. Metode Penelitian Kualitatif. Bandung : PT Remaja Rosdakarya 
Mulida, Y. 2018. Peluang dan Tantangan Pengembangan Usaha Mikro Kecil Dan Menegah (UMKM) dari Berbagai Aspek Ekonomi. Jurnal Ilmiah Bisnis dan Ekonomi:
Nasikun. 2006. Sistem Sosial Indonesia, Jakarta: PT Raja Grafindo Persada.

Soekanto, S. 2012. Sosiologi Suatu Pengantar, Jakarta: PT Raja Grafindo Persada. 